\title{
SCIENCE AND IDEOLOGY
}

\section{THE CASE OF PHYSICS IN NAZI GERMANY}

\section{PHILIP BALL}

Science is not «above" politics and ethics: it is intrinsically political, and constantly raises ethical dilemmas. The consequences of evading such issues were made particularly clear in the actions of scientists working in Nazi Germany in the 1930s and 40s. The accusation in 2006 that Dutch physicist Peter Debye was an opportunist who colluded with the Nazis reopened the debate about the conduct of physicists at that time. Here I consider what those events can tell us about the relationship of science and politics today. I argue that an insistence that science is an abstract, apolitical inquiry into nature is a myth that can leave it morally compromised and vulnerable to political manipulation.

Keywords: Nazism, German physics, science and politics, Peter Debye.

Science, it is often said, must be free from ideology. Scientists should seek knowledge that is independent of the prevailing sociopolitical preoccupations, and not allow political views to enter their work. Many scientists believe the corollary: that when science does encounter political interference, it is compromised, perhaps fatally. But neither of these things is necessarily true.

In his 1969 analysis of science's response to the politics of its time, historian Joseph Haberer concluded that «an idealization of science as a superior form of activity remains deeply entrenched in the contemporary scientific consciousness» (Haberer, 1969). The belief that science should somehow be «above» politics, Haberer showed, has been evident at least since the inception of modern science in the seventeenth century. One can say that it remains widespread today.

Scientists often argue that they cannot be expected to be proficient in making moral, ethical and political judgements as well as technical ones. And how can they possibly expect to foresee the ways in which their work will be applied, let alone then ensure that only beneficial uses are pursued? If they were to be held accountable for such applications, would they not either be regulated and constrained beyond measure, not to mention legally vulnerable, or lose all their time to bureaucracy?

But although it is true to say that scientists have no special moral competency, the statement is somewhat self-fulfilling. Scientific training rarely incorporates an ethical dimension. Even when it does, the emphasis tends to be solely on codes of professional conduct: issues such as intellectual property, citation, treatment of staff, conflicts of interest and whistle-blowing. Yet there are broader responsibilities too, as the development of nuclear weapons during the Second World War made clear by revealing how socially and politically transformative, not to mention how destructive, a new technology can be.

In the light of developments such as genetic engineering and nanotechnology, there is far greater awareness today that new technologies raise important societal and ethical questions that should be debated within and beyond the scientific community in parallel with their technical development. Yet this has not necessarily bred a readiness in scientists to engage with these matters beyond the role of offering technical advice. A common response is to acknowledge that these are 
important questions but to insist that they must be left for «others», or for «society», to decide.

Nonetheless, the Manhattan Project and the nuclear arms race that followed played a big part in cultivating among scientists a recognition of wider responsibility. So have many other episodes since then, among them environmental despoliation and climate change, thalidomide, the link between smoking and cancer, genetic engineering, Chernobyl, AIDS, embryo research and synthetic biology. It would be unfair to suggest that science continues doggedly to insist on its abstract purity and detachment from morality and politics.

An important acknowledgement of the scientist's ethical duties occurred in 1975, when many leading biologists came together at the Asilomar Conference Center in Monterey, California, to discuss the implications of new techniques in genetic engineering: the ability to excise and insert genes into DNA. Such methods are now one of the dominant influences on molecular biology, being central not only to the creation of genetically modified organisms for research, agriculture and breeding, but also to new forms of medicine (gene therapies), cloning, and genomic profiling. As one attendee, the Nobel laureate biochemist Paul Berg, has put it, «Looking back now, this unique conference marked the beginning of an exceptional era for science and for the public discussion of science policy» (Berg, 1980).

Although Asilomar demonstrated a commendable readiness to consider consequences and accept inconvenient conclusions, Berg doubts whether the same approach will work today for some of the ethical issues raised by genetic and biomedical research, such as embryo research and stem-cell technology. It is one thing to evaluate objective health risks, even though this alone is hard enough in the face of unknown consequences and the vagaries of public risk perception. But when science confronts deeply held social and religious values, it is far from clear that a consensus can ever be reached, even by compromise. Society has to find some way of accommodating irreconcilably different views.

Much has changed since Haberer delivered his rather damning judgement on the political and moral acumen of scientific communities four decades ago, not least the growing awareness that science has a central role in tackling global crises such as environmental change and epidemic disease. But many scientists still cling to the shibboleth that their business is «apolitical», a search for truth unsullied by worldly affairs. When the state does intrude on and interfere with science, scientists still struggle to find

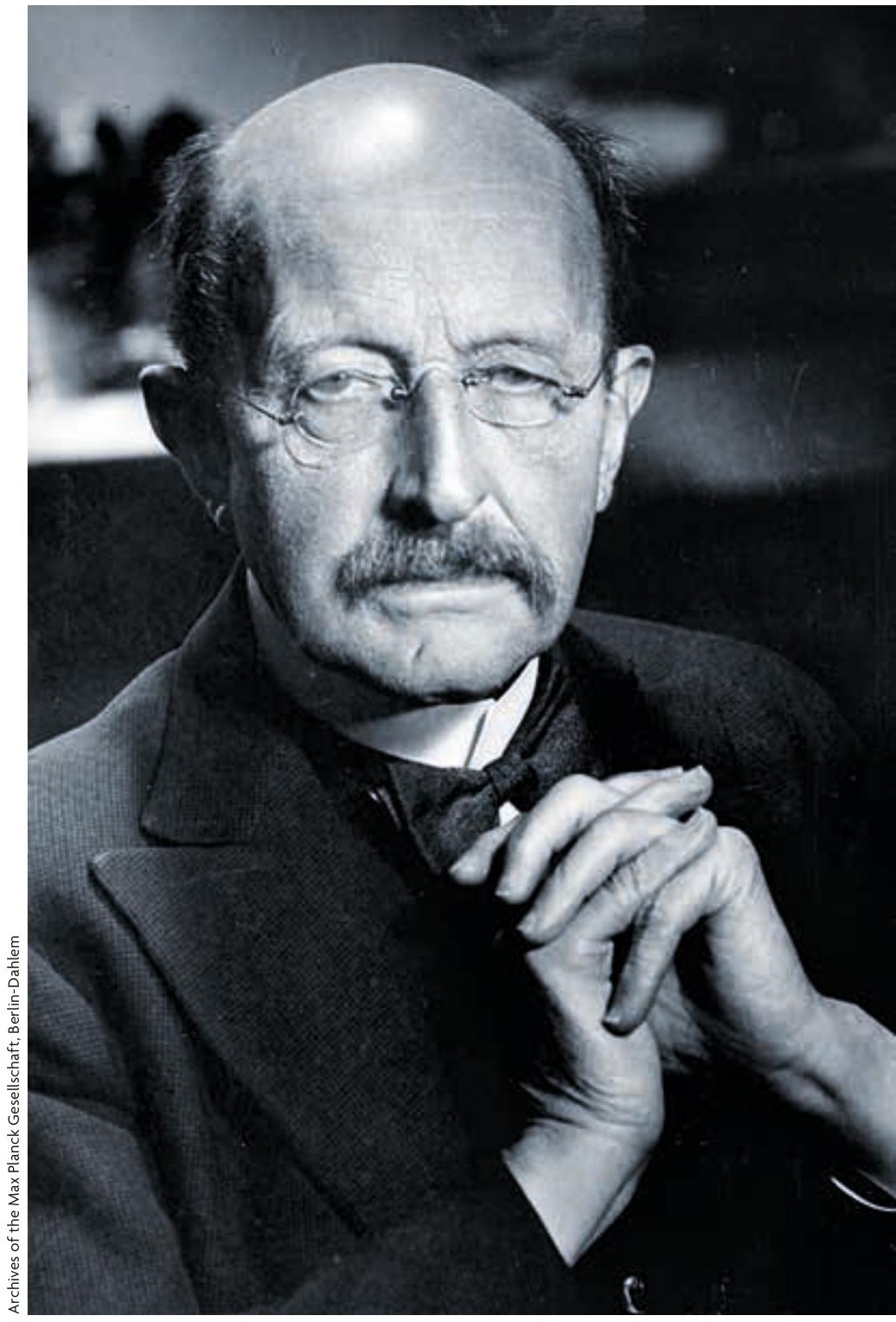

Max Planck was the president of the Kaiser Wilhelm Society (KWS) that administered key institutes of German science. He was on holiday when the news of the Civil Service Laws - expelling Jews and political opponents from places of power and influencebroke in April 1933, and saw no pressing need to return and deal with the implications. This was not indifference but a grave misapprehension of the nature of the National Socialist programme. In the image, Max Planck in 1936.

«THE EXAMPLE OF PHYSICS IN NAZI

GERMANY HAS MESSAGES FOR

THE CONDUCT AND RESPONSIBILITIES

OF SCIENTISTS THAT REMAIN RELEVANT TODAY» 
effective means of resistance. While one cannot expect scientists to be braver or more morally astute than any other section of the population, science can and should as a community organize itself to maximize its ability to act collectively, ethically and - when necessary politically. That objective would need to include more explicit recognition of the political nature of science itself. The practice of science, Haberer said, «is infused with problems which require political modes of thought and political instrumentalities» (Haberer, 1969).

\section{PHYSICS UNDER HITLER}

The consequences of a lack of political engagement and ethical reflection became painfully clear in Germany shortly before and during the period of Nazi rule (19331945) (Ball, 2014; Macrakis, 1993; Walker, 1995). The common view is that most German scientists gritted their teeth and got on with their research as best they could under compromised circumstances. Some have even suggested that the German physicists actively resisted collaboration with the government by dragging their heels or falsifying their calculations to ensure that Hitler did not have weapons of mass destruction at his disposal (Powers, 2000).

This story is largely a myth. Partly it seems to be perpetuated because it fits with what many scientists would like to believe about their profession. But the myth was also in part an active attempt to salvage the reputation of German physics (Rammer, 2012) by applying what historian Dieter Hoffmann has called «formula of exoneration» (Hoffmann, 2005).

This debate about how to judge the response of the German physics community to Nazi rule continues to rage. It was reawakened in 1998 by Michael Frayn's play Copenhagen, which examined the discussions in Nazi-occupied Denmark in 1943 between Werner Heisenberg, who arrived as a cultural ambassador for the German state, and his former mentor Niels Bohr. Controversy also flared up in 2006 following the publication of a book in which the Dutch physicist and Nobel laureate Peter Debye was accused of collusion with the Nazi regime (Rispens, 2006) - an accusation that led temporarily to the removal of Debye's name from a Dutch university institute and a scientific award (Eickhoff, 2008).
Did these scientists demonstrate any serious opposition to the totalitarian and anti-Semitic policies of the German National Socialists, or did they on the contrary adapt themselves to the regime? Was science commandeered and undermined by the National Socialists? These questions will not be addressed by trying to divide up German physicists between camps labelled «good» and «bad». It was impossible to remain in Nazi Germany without making compromises of some sort, and the vast majority of scientists were caught in a grey area between complicity and resistance. Rather than trying to condemn or exonerate individuals with comfortable hindsight, it is more useful to consider how the scientific community as a whole acted in such extreme circumstances.

Precisely because they were extreme, one must be careful about drawing any general conclusions about the way science responds to its political situation. Nonetheless, we have an obligation to look for such generalizations if we are going to learn from the past. In many ways the enormity of the situation simply threw a harsher spotlight on tendencies that already existed within the community - some of them shared with German society as a whole, others arguably unique to science. And although the world has changed in the past eight decades, there is good reason to believe that the example of physics in Nazi Germany has messages for the conduct and responsibilities of scientists that remain relevant today.

\section{ARYAN PHYSICS AND NON-ARYAN EXPULSIONS}

Anti-Semitism festered in Germany long before the Nazi era. In physics it was given a prominent voice by Philipp Lenard, who won the 1905 Nobel Prize for his studies of cathode rays. In connection with this work, Lenard investigated the photoelectric effect - the expulsion of electrons from metals irradiated with ultraviolet light - and when in 1905 Einstein explained aspects of the effect in terms of Max Planck's quantum hypothesis, Lenard felt his discoveries had been stolen. His bitterness deepened when Einstein was awarded the 1921 Nobel Prize in Physics for that work. Lacking the mathematical skills to cope with relativity and quantum theory, both of which Einstein pioneered, Lenard decided they were wrong and that their 
widespread acceptance and acclaim were the result of a pro-Jewish conspiracy (Beyerchen, 1977).

Lenard was not the only influential scientist to attack Einstein in anti-Semitic terms. The 1919 physics Nobel laureate Johannes Stark was another experimentalist confused and angered by the mathematical complexity that had recently entered physics. Like Lenard he was an extreme nationalist whose right-wing views were hardened by the First World War, and the two of them found common cause. In May 1924 they wrote an article called «The Hitler spirit and science», pledging support to the Nazi leader (Mosse, 1966). Lenard and Stark advocated an «Aryan physics» (Deutsche physik), which they wanted to replace the decadent «Jewish physics» of Einstein and his supporters.

Adolf Hitler was appointed Reichschancellor at the end of January 1933. Very quickly, Germany became a dictatorship as Hitler suspended civil liberties and imposed press censorship. In March the Nazis passed the Enabling Law, which gave Hitler power to legislate without the consent of the Reichstag and even to overrule the Constitution. The Civil Service Law followed in April, expelling Jews and political opponents from places of power and influence.

In Germany in the 1930s the so-called «Jewish question» was not regarded as a matter of basic human rights; it was a political matter, and therefore not something an academic should be concerned with. One could deplore the bad treatment of Jews - and many did - without feeling placed under any obligation to act or speak publicly about it in a professional capacity.

And so there were no prominent resignations among physicists who were not directly affected by the new laws. What good would resignation do, people asked? It would only deplete German physics further, without changing anything else. When some German scientists did dare to express concerns about Jewish expulsions, these were always couched in terms of the harm that the losses would do to German science, not in terms of the immorality of the laws. Many felt that the hardline aspects of Nazi rule would soften anyway, or that Hitler would soon lose power. The best course seemed to be to keep quiet and weather the storm. Max Planck, president of the Kaiser Wilhelm Society (KWS) that administered key institutes of German science, was on holiday in Sicily when the news of the Civil Service Laws broke, and saw no pressing need to return and deal with the implications. This was not indifference but a grave misapprehension of the nature of the National Socialist programme.

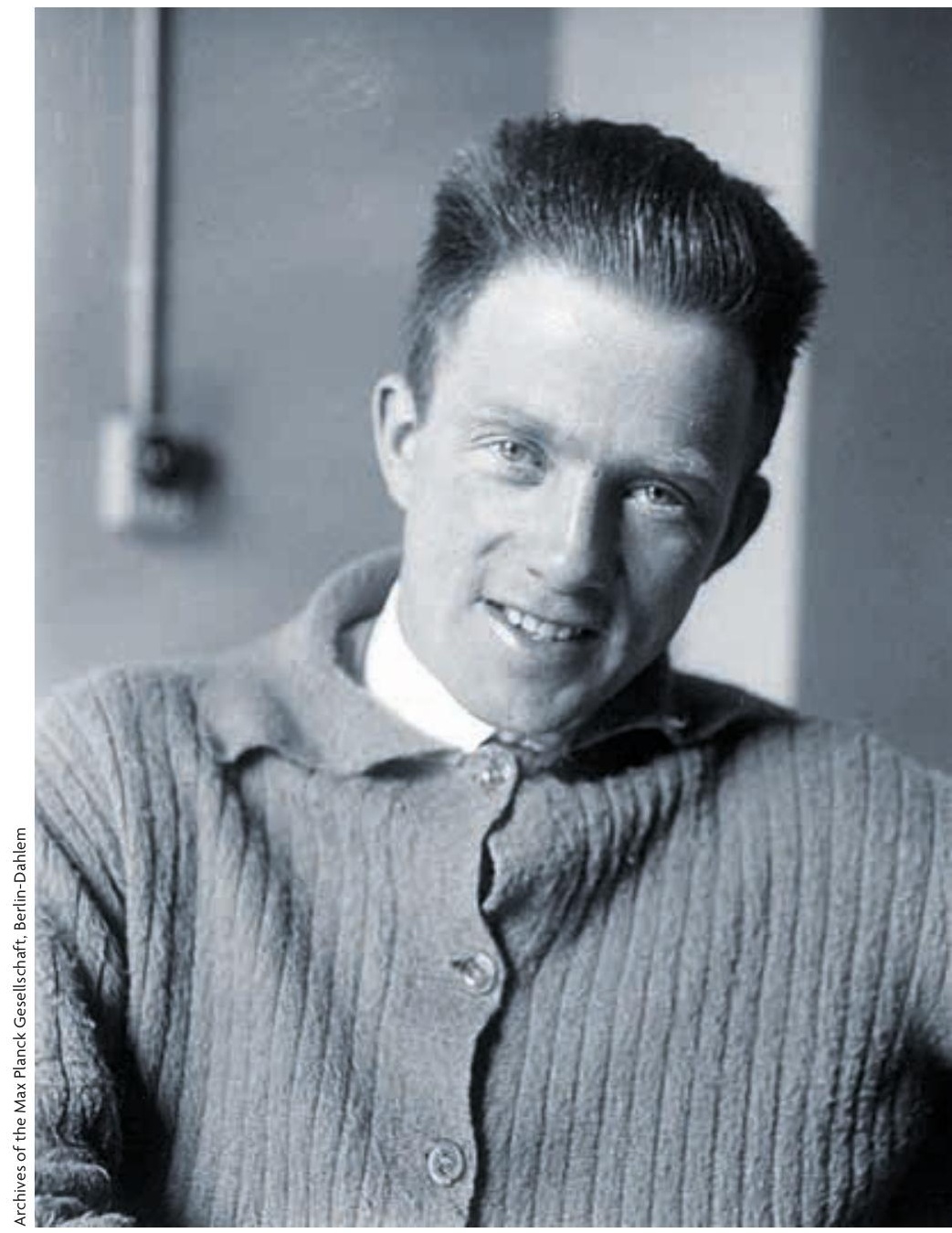

After the war, Werner Heisenberg presented himself as a covert opponent to the Nazis. He insisted that his inaction and accommodation during the Nazi era was in fact the only form of "active opposition" that could have had any effect. In the photograph, Werner Heisenberg in 1927.

Planck had been brought up to observe complete obedience to the state, and had no idea what to do when the state turned out to be corrupt. His position is more tragic than despicable (Heilbron, 2000).

After Hitler's election Stark was made president of the prestigious Institute of Physics and Technology of the German Reich (PTR) in Berlin. He announced that the PTR would thenceforth take charge of all German scientific periodicals. He instigated the «Führer principle» that the Nazis wished to see applied in all areas of life, and sacked all Jews from the advisory committee. But Stark and Lenard were angered that their colleagues seemed so slow to embrace the new regime; they felt that the KWS in particular was shamefully lax about expelling its 
Jewish members. And certainly, the organization sought ways to resist political interference. When Max Planck retired as president after his second term of office ended in 1936, the senate elected as his successor the industrialist and chemistry Nobel laureate Carl Bosch, who as a non-academic was thought to be more immune to political pressure. But the Reich Education Ministry appointed the Nazi official Ernst Telschow as secretary of the KWS, and although it was not exactly nazified in the pre-war period, neither did it mount any effective resistance to the wishes of the government. In 1937 it expelled the remaining Jewish members.

\section{THE WHITE JEWS OF PHYSICS}

One of the physicists most affected by Deutsche physik was Werner Heisenberg. Stark held a grudge against him ever since he had refused to attend a rally of the National Socialist Teachers League in Leipzig in November 1933. Then at a gathering of the Society of German Scientists and Physicians in Hannover in September 1934, Heisenberg defended relativity and quantum theory against Stark's accusations that they were speculative, and he even mentioned Einstein by name, earning him an official reprimand.

In an address in Heidelberg in December 1935, Stark called Heisenberg a «spirit of Einstein's spirit» (Cassidy, 2009). This speech was printed in the January issue of the Party periodical Nationalsozialistische Monatshefte. The following July Stark published in the SS journal Das Schwarze Korps a vilification of Heisenberg and others (such as Planck and Sommerfeld) who colluded in the «Jewish conspiracy» in physics without being themselves Jewish. These people, he said, were «White Jews»: a designation calculated to make them the legitimate targets of all the abuse heaped on the Jews themselves.

Desperate to retain his good name in Nazi Germany, Heisenberg appealed directly to Heinrich Himmler to save his «honour». Himmler ordered an investigation into Heisenberg's character, and the Gestapo and SS bugged his house, placed spies in his classes, and questioned him on several occasions. This exhausting and frightening process finally resulted in a report that exonerated Heisenberg, portraying him as an «apolitical» scientist who was basically positive towards National Socialism and a good patriot. In July 1938 Himmler finally wrote to Heisenberg, saying «I do not approve of the attack of Das Schwarze Korps in its article, and I have proscribed any further attack against you» (Cassidy, 2009). He also advised, however, that Heisenberg would do well not to mention Einstein in future. Heisenberg complied: in an article published in a Nazi periodical in 1943, he acknowledged Einstein's discoveries while suggesting that they would have happened anyway.

Heisenberg's biographer David Cassidy explains that Heisenberg came to feel that the reputation of all German physics rested with him. «By seeing himself in such a grandiose rationalization for remaining in Germany», Cassidy writes, «he more easily succumbed to further compromises and ingratiation with the regime» (Cassidy, 2009). Heisenberg made his science a refuge from moral dilemmas, a higher plane untroubled by what he called «money politics». After the war he presented himself as a covert opponent to the Nazis, saying for example to the Dutch Jewish exile Samuel Goudsmit that «I knew... if we Germans did not succeed in undermining this system from the inside and finally to remove it, then an enormous catastrophe would break loose which would cost the lives of millions of innocent people in Germany and other countries» (Heisenberg, 1948). He insisted that his inaction and accommodation during the Nazi era was in fact the only form of active opposition that could have had any effect. In response, Goudsmit rightly pointed out that the German physicists had been largely silent on the morality of the regime under which they had served (Goudsmit, 1948).

\section{IN THE CASE OF PETER DEBYE}

Questions about where passive acceptance of the situation merges with collusion are still more complicated in the case of the Dutch physicist Peter Debye, the 1936 Nobel laureate who made his career for the most part in Germany and became one of its most powerful representatives (Ball, 2014; Eickhoff, 2008; Hoffmann \& Walker, 2011). Debye was unusual in having both experimental 
and theoretical expertise, his particular speciality being the interactions of atoms and molecules with electric fields and electromagnetic radiation $-\mathrm{a}$ topic that relied increasingly on the new concepts introduced by quantum theory. When the Nazis came to power, Debye was, like Heisenberg, a member of the faculty at Leipzig University. But in 1934 Max Planck appointed Debye as director of the new Kaiser Wilhelm Institute for Physics (KWIP), built in Berlin with funding from the philanthropic Rockefeller Foundation in America.

Then in the autumn of 1937 Debye was elected as chairman of the German Physical Society (DPG, for its German acronym). This was one of the few official organizations in Germany still not to have rigorously excluded all its Jewish members, although many had left of their own accord and very few remained by this stage. The government authorities made it clear that these few too must be expelled, and Debye saw that the DPG might simply be taken over by the Nazis if it did not comply. In December of 1937 he sent a letter to members asking all classed by the Nazi laws as Jews to withdraw from membership.

This is not the prima facie evidence of collusion that it has sometimes been made out to be. If the DPG had not taken this step voluntarily, it would doubtless have been compelled to do so, with Debye being replaced by someone more compliant. The standard view among Debye's colleagues was that resignations were a worthless gesture of defeat and cowardice. All the same, none seemed seriously able to consider what was achieved practically, or what was sacrificed morally, by staying in one's post in a case like this.

There was more interference to come. In late 1938 , Otto Hahn, the director of the Kaiser Wilhelm Institute for Chemistry in Berlin, and his assistant Fritz Strassmann discovered experimental evidence for nuclear fission in uranium - an interpretation explained by Lise Meitner, who had been forced to flee to Sweden in July of that year but to whom the new puzzling findings were conveyed. It was immediately clear that uranium was a potential source of vast amounts of energy, which might be released in a controlled way to generate power, or in an uncontrolled way in a bomb of inconceivable destructiveness. When the Nazi authorities were informed, they decreed that the KWIP would be
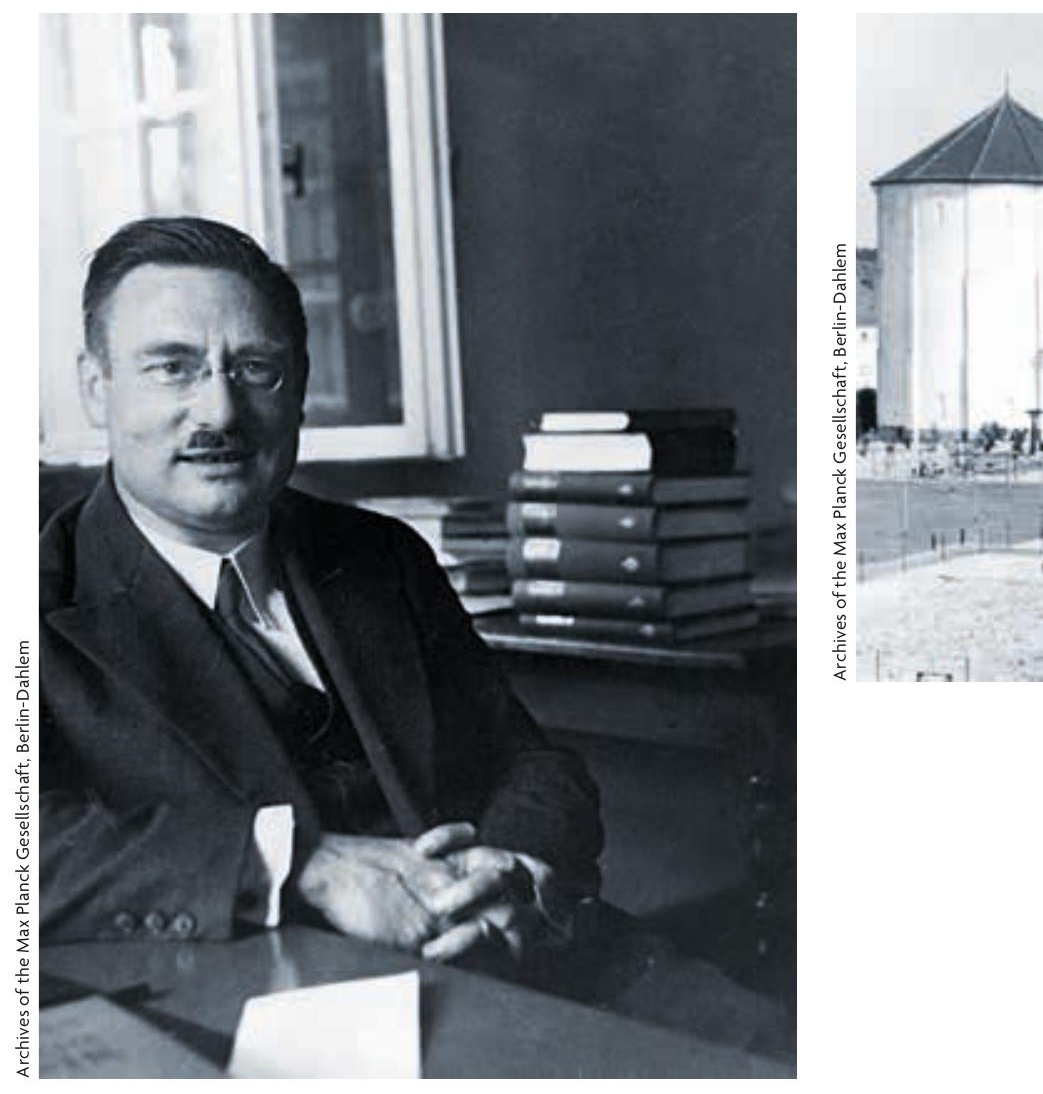

immediately given over to research on nuclear energy. With war in Europe now looking inevitable, a project this sensitive could not be entrusted to a nonGerman - and so, two weeks after Britain declared war on Germany, Debye received a letter informing him that he must henceforth either relinquish his Dutch citizenship and become German, or resign. Instead, Debye negotiated a six-month leave of absence, during which time he would take up an invitation to deliver a series of lectures at Cornell in America. He left Europe in early January of 1940.

In America Debye told the officials at the Rockefeller Foundation about the nuclear research being planned at the KWIP, of which Werner Heisenberg eventually became director. It was partly this information that led Einstein and Leo Szilard to recommend to President Roosevelt the large-scale research project on the liberation of nuclear energy that eventually became the Manhattan Project. Debye was not granted official clearance to work on that 


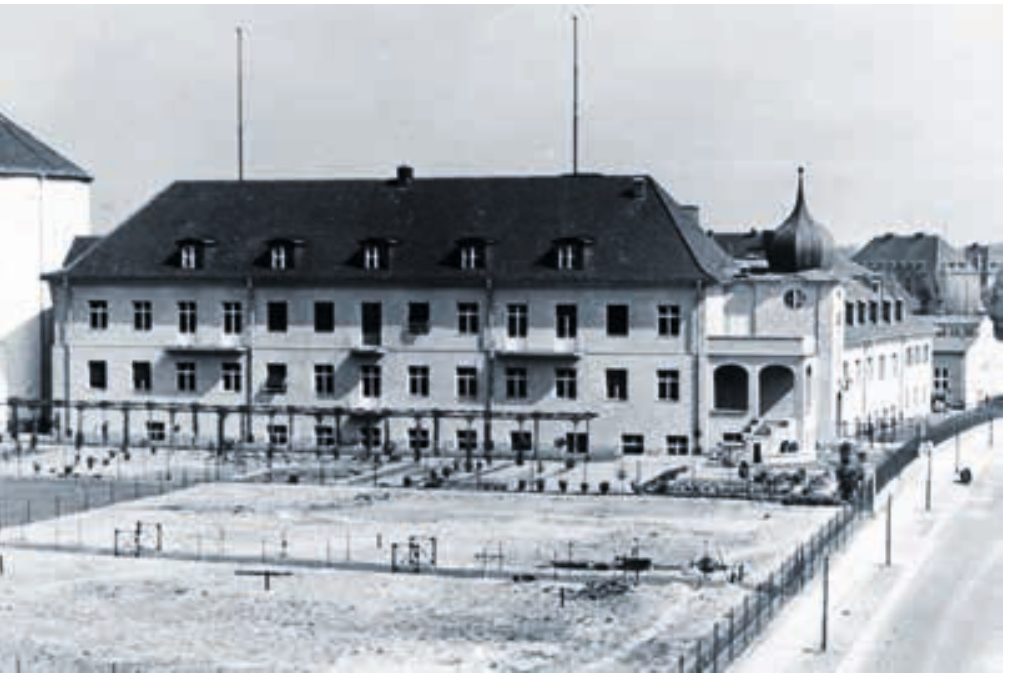

In 1934, Max Planck appointed Peter Debye (on the left in a picture circa 1936) as director of the new Kaiser Wilhelm Institute for Physics (above these lines), built in Berlin with funding from the philanthropic Rockefeller Foundation in America. perhaps his statement in 1937 that provided his guiding principle? He had said: «It is always my custom to ask myself in what way I can be most useful for physics. That is the first consideration for me and other more personal considerations play a more secondary role» (Van Ginkel, 2006).

For scientists at that time, particularly in Germany, nothing would have seemed more noble than this determination to live and work only for science, free from the messy compromises and ambiguities of the political world. In a letter Debye wrote to his mentor Arnold Sommerfeld on the eve of his departure from Germany at the end of December 1939, we can find the essence of why he has been both attacked and defended. His philosophy, he wrote, was: «Not to despair and always be ready to grab the good which whisks by, without granting the bad any more room than is absolutely necessary. That is a principle of which I have already made much use» (Van Ginkel, 2006).

One could interpret this simply as an intention to remain optimistic, looking for ways to contribute something of value and to avoid harmful actions as far as possible - or as an indication that Debye was not prepared to change or challenge anything, but just to take advantage of whatever opportunities came his way. Which is correct? Debye gives no sign of having pondered the distinction himself. Perhaps his is simply a statement of shallow optimism, which will work well enough unless circumstances render it untenable. In Nazi Germany Debye appears to have been out of his moral depth.

citizen and never did go back to Berlin. Was this just opportunism? Or does it show that he emphatically rejected the Nazis and all they stood for? During Debye's lifetime, these questions were never really asked, and he never raised them himself. Yet his flight from Germany was precipitated not by his abhorrence of Nazi policies, as some later accounts of his life seemed to imply, but by the demand that he renounce his Dutch nationality. If the Nazis had been prepared to tolerate a foreign national as the head of the physics institute, there seems no telling what Debye would have done. His family today insist that his mind was already set on leaving Germany, but there is no indication that, until he was served the ultimatum in September 1939, he had any plans to do so.

Debye surely faced a difficult choice. But what weighed most heavily in his decisions? The injustices and immorality of a regime that, by 1939, had become evidently barbaric? The good of his family? Or was it

\section{ARE SCIENTISTS SPECIAL?}

Debye has been called «an ordinary man in extraordinary circumstances» (Hoffmann \& Walker, 2006). While this formulation risks generalizing his particular weaknesses, it rings true in the sense that there was nothing especially egregious in those failings. Debye's occasional self-interest and limited moral engagement, Heisenberg's insecurity and egotism, Planck's prevarication and misconceived notion of duty - none are profound character flaws, and all would have been minor blemishes on a fundamentally decent nature in happier circumstances.

The more pertinent question is whether there is any reason to expect from Planck, Heisenberg and Debye something more than their compromised, halting and 
ambivalent moral stance, purely because they were scientists. Did their positions as leading members of the German physics community create obligations and expectations any more demanding than those one might impose on anyone else?

Yet the refusal to confront the ethical questions was not merely passive, but active. It was a common belief among German scientists between the wars that the proper conduct of their profession entailed an «apolitical» withdrawal into the realm of logic, abstraction and «truth». Because he engaged with worldly affairs, Einstein was condemned sometimes even by those who revered his work for «making science political». This conviction can still be detected in researchers today. Scientists pride themselves on offering facts, not opinions, and some insist on a distinction between the purity of scientific discovery and the dirty realities of its application.

The naivety of such a position was exposed in Nazi Germany. On the one hand, an «apolitical» stance left the scientists vulnerable to political manipulation. At the same time it was a façade, for the scientists used the bait of nuclear power to extract funds from the regime. They did not secure enough to come close to making a bomb by the end of the war, but that seems to have been primarily because they lacked any conviction that they could provide it, and did not wish to risk a failure to deliver; Manhattan-Project-scale money was allotted instead to the German rocket program.

It was through evasions, delusions and diversions, not collusions, that most scientists accommodated themselves to National Socialist Germany. Their vision was too narrow, their standards too conservative. It was not so much that these men blindly followed a redundant notion of duty, but that they seem actively to have constructed an idea of «duty to science» as a way of denying broader responsibilities. In that way, many German scientists found in their profession a justification for avoiding questions of social justice and probity.

\section{CONCLUSIONS: SCIENCE AND DEMOCRACY}

Seen against the wider historical backdrop, the behaviour of German physicists under the Nazis was not an aberration under extreme circumstances, but a fairly typical example of how science and politics
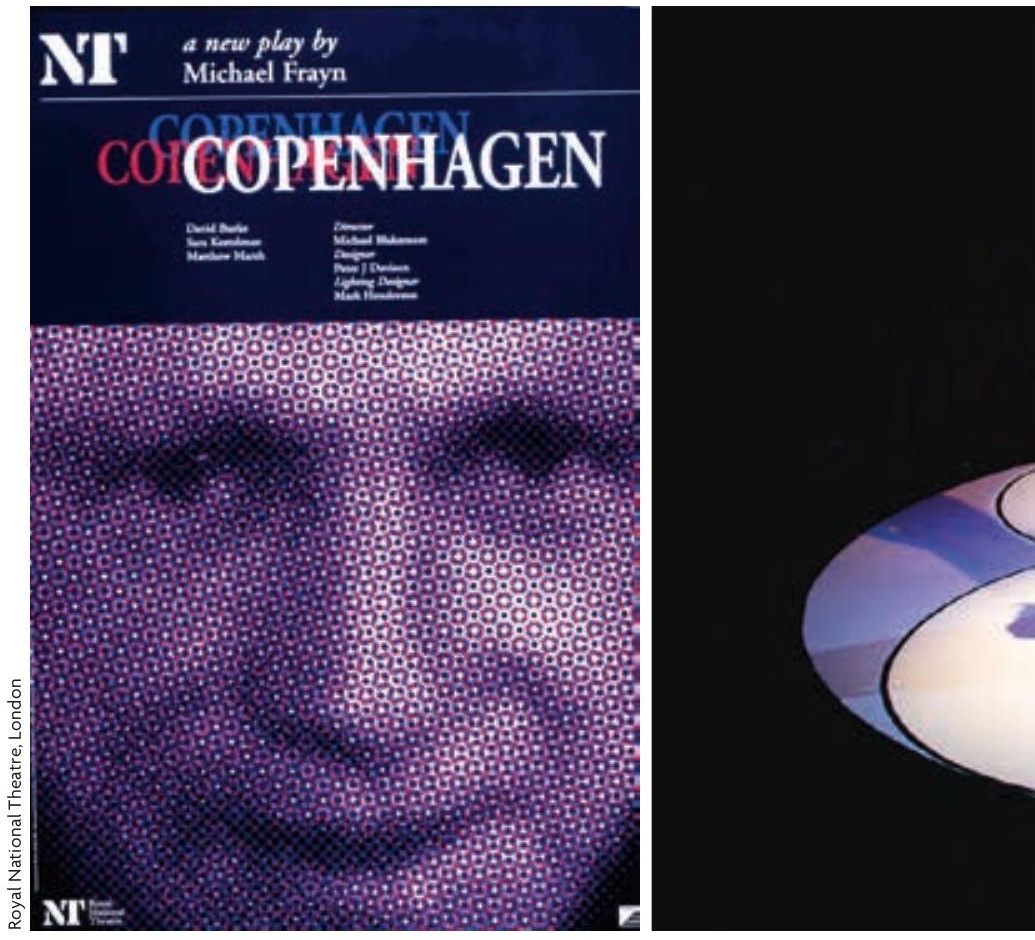

This debate about how to judge the response of the German physics community to Nazi rule continues to rage. It was reawakened in 1998 by Michael Frayn's play Copenhagen, which examined the discussions in Nazi-occupied Denmark in 1943 between Werner Heisenberg, who arrived as a cultural ambassador for the German state, and his former mentor Niels Bohr. In the pictures, original poster for the premiere and a photograph from a representation in 2013 interact. While German National Socialism cannot stand proxy for every autocracy in the modern world, the fate of science under its auspices challenges some preconceptions about the relationship of research and political democracy. Many Western scientists cleave to the idea that science can only truly flourish in a wholly free society. This attitude is unduly selfcongratulatory. There is ample evidence that oppressive regimes can foster the technical expertise needed to develop destructive weapons and other unwelcome technologies (Walker, 2003). German scientists under Nazi rule were perfectly able to conduct vibrant and productive science - just as, during the height of the Cold War when state oppression in the Soviet Union was even more extreme, Soviet scientists were capable of innovative and effective scientific research. All but the most fanatical regimes will recognize the 


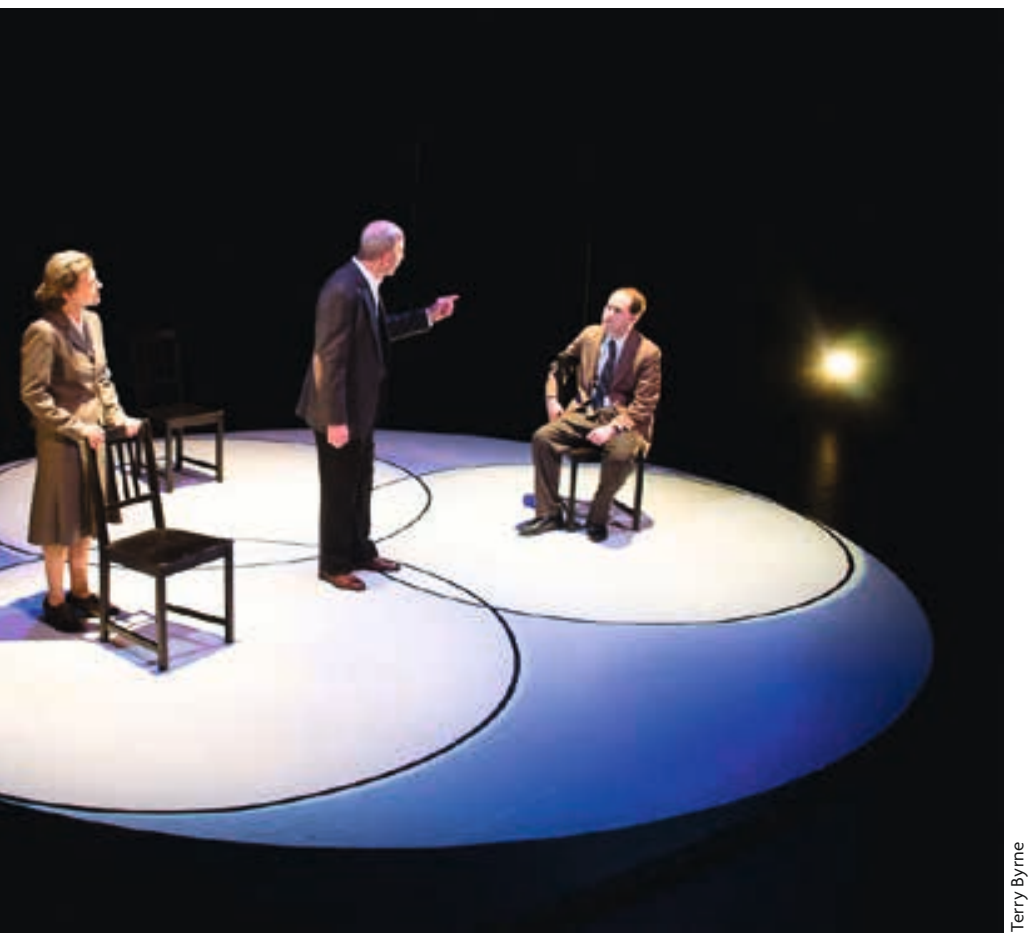

systems for guarding against such interference. But the assumption that democracy guarantees good science, and that totalitarianism makes it impossible, finds little support in history.

\section{REFERENCES}

Ball, P. (2014). Serving the Reich. London: Bodley Head.

Berg, P. (1980). Asilomar and recombinant DNA. Nobel Lecture. Retrieved, from www.nobelprize.org/nobel_prizes/chemistry/laureates/1980/ berg-article.html

Beyerchen, A. D. (1977). Scientists under Hitler: Politics and the physics community in the Third Reich. New Haven: Yale University Press.

Cassidy, D. C. (2009). Beyond uncertainty: Heisenberg, quantum physics, and the bomb. New York: Bellevue Literary Press.

Eickhoff, M. (2008). In the name of science? P. J. W. Debye and his career in Nazi Germany. Amsterdam: Aksant.

Goudsmit, S. (1948, 20 September). Letter to W. Heisenberg (box 10, folder 95). Samuel Goudsmit Papers, American Institute of Physics.

Haberer, J. (1969). Politics and the community of science. New York: Van Nostrand Reinhold.

Heilbron, J. L. (2000). The dilemmas of an upright man: Max Planck and the fortunes of German science. Cambridge, MA: Harvard University Press.

Heisenberg, W. (1948, 5 January). Letter to S. Goudsmit (box 10, folder 95). Samuel Goudsmit Papers, American Institute of Physics.

Hoffmann, D. (2005). Between autonomy and accommodation: The German Physical Society during the Third Reich. Physics in Perspective, 7(3), 293-329. doi: 10.1007/s00016-004-0235-x

Hoffmann, D., \& Walker, M. (March 2006). Peter Debye: A typical scientist in an untypical time. Deutsche Physikalische Gesellschaft. Retrieved from www. dpg-physik.de/dpg/gliederung/fv/gp/ debye_en.html

Hoffmann, D. \& Walker, M. (Eds.). (2011). «Fremde» Wissenschaftler im Dritten Reich. Die Debye-Affäre im Kontext. Göttingen: Wallstein Verlag.

Macrakis, K. (1993). Surviving the swastika: Scientific research in Nazi Germany. New York: Oxford University Press.

Mosse, G. L. (Ed.). (1966). Nazi culture: Intellectual, cultural and social life in the Third Reich. New York: Grosset \& Dunlap.

Powers, T. (2000). Heisenberg's War. Boston: Da Capo.

Rammer, G. (2012). «Cleanliness among our circle of colleagues»: The German Physical Society's Policy toward its past. In D. Hoffmann, \& M. Walker (Eds.), The German Physical Society in the Third Reich. Cambridge: Cambridge University Press.

Renneburg, M., \& Walker, M. (Eds.). (1994). Science, technology and national socialism. Cambridge: Cambridge University Press.

Rispens, S. I. (2006). Einstein in Nederland: Een intellectuelle biographie. Amsterdam: Ambo.

US House of Representatives Committee on Oversight and Government Reform. (2007). Political interference with climate change science under the Bush Administration. Retrieved from www.cfr.org/climatechange/political-interference-climate-change-science-under-bushadministration-december-2007/p15079

Van Ginkel, G. (2006). Prof. Peter J. W. Debye (1884-1966) in 1935-1945: An investigation of historical sources. The Netherlands: RIPCN.

Walker, M. (1995). Nazi science: Myth, truth and the German atomic bomb. New York: Plenum.

Walker, M. (Ed.). (2003). Science and ideology: A comparative history. London: Routledge.

Philip Ball. Science writer and author (London, UK). He previously worked as an editor at Nature, and his many books on science and its interactions with the broader culture include Serving the Reich: The struggle for the soul of physics under Hitler (2014). 